\title{
THE NATURE OF THE HUMAN FACTOR IN INFANTILE PARALY- SIS. I. PECULARITIES OF GROWTH AND DEVELOPMENT ${ }^{1}$
}

\author{
By GEORGE DRAPER AND C. WESLEY DUPERTUIS \\ (From the Department of Medicine, College of Physicians and Surgeons, Columbia University \\ and the Presbyterian Hospital, New York City)
}

(Received for publication October 7, 1938)

Since the great epidemic of infantile paralysis in 1916 research in every phase of the subject has been actively maintained. Explorations into the nature of the virus, portal of entry, epidemiology, prevention, and treatment have been vigorously pursued. In the Constitution Clinic of the Presbyterian Hospital our interest has been concerned especially with the evaluation of the personal identity or constitutional characters of the paralyzed child or adult. The present research was originally undertaken in 1916 for the following reasons: First, the general principle that Human Disease represents a conflict between a living individual and some specifically adverse element of its environment; second, that in the most heavily infected areas many children of susceptible age remained well; third, that in the presence of an identical sample of virus there was great variation in the severity of the clinical course; fourth, that there was a notable difference between the morphology of stricken and well children.

Our observations upon these constitutional differences have been published from time to time since their first mention in $1917(1,2)$. As in our previous studies the morphology of stricken persons has been our initial avenue of approach to the questions: "Are the subjects of any given disease constitutionally different and recognizable from those individuals who escape that particular malady?" A dissenting view of this thesis in the case of infantile paralysis is taken by Levine, Neal, and Park (3) and also by Thelander and Pryor (4). It is interesting to note, however, that earlier clinicians mentioned that poliomyelitis victims were notable for their large size, robustness, and sound teeth. Thus Underwood (5) in 1799 referred to "fine children" and in 1823 Shaw (6) wrote "strong and healthy children are more frequently affected than those of a

1 The work reported in this communication was carried out under a grant from the Rockefeller Foundation. weakly constitution." There are many other similar statements by other authors, including Aycock (7), who also have observed differences between the constitutional types of stricken and well subjects. From these writings it would appear that the notion of a "host factor" in acute poliomyelitis was stirring as early as 1799 , perhaps even before the infectious idea was born. Furthermore, since morphology is clearly, at least in part, an inherited character, the question has often been asked whether other qualities such, for example, as immunity might likewise be a genetic one. The recent work of Webster $(8,9)$ indicates that certain breeding techniques markedly influence the resistant or susceptible factor in some strains of mice to both bacterial and virus infections. "Heredity" he states, "has proved clearly to be an element of fundamental importance in determining the fate of individuals following primary exposure to a natural infection." And again, in a subsequent paper "The thesis of variability of host resistance and its regulation by inborn and environmental factors has both particular and general bearing upon experimentation in infectious disease. ... Again the rôle of innate resistance factors is being investigated in experimental epidemiology, for example, in the matter of determining the status of survivors of an epidemic. Are they inherently resistant at the outset and spared from the ravages of the epidemic agent, or are they differentiated only by the chance exposure to subinfectious doses which have immunized them, or do both processes participate?"

Furthermore, so far as infantile paralysis is concerned, we have evidence in our clinic (not reported), and numerous other observers, notably Aycock (10), have published genetic histories which indicate beyond doubt that the disease may well " run in families."

The purpose of this communication is to support further our contention that persons suscep- 
tible to the adverse effects of poliomyelitis virus are highly specialized types of the human race, that they possess a recognizable physical constitution which is determined by inherited faults or adverse intrauterine environment, or both. These result in growth and development irregularities, retardations, and endocrine imbalance of a definite character which appear to correlate with susceptibility to the virus.

\section{MATERIAL}

Measurements and observations upon 148 paralyzed boys, 125 paralyzed girls, and a control group of 229 "well boys" all between the ages of 5 and 20 compose the material of this investigation. There is no control series of well girls, but it turned out that the paralyzed females were similar to the paralyzed males (excepting primary sex characters) in all measurable and nonmeasurable (observed) characters. To facilitate the statistical reduction of the data, the series were divided into age groups of 2-year intervals. Ages 15 to 20, because of paucity of numbers were combined in one unit. In the male paralyzed series, the number of cases in each group varied from 20 to 33 ; in the control series from 20 to 57 ; in the female paralyzed series 16 to 26 . Without regard to the time they were attacked the subjects have been grouped according to their age at the time they were measured.

The racial factor was carefully studied. But after adding to our New York material a series of 31 (both sexes) paralytics in Sweden and 27 cases in Finland, ${ }^{2}$ and a large control group of well boys and girls from Swedish summer camps, we conclude that among white people, at least, race apparently plays a negligible rôle in susceptibility to infantile paralysis.

We have continued to apply the technique of measurement and observation which we have pre-

2 It gives us great pleasure to express our thanks to Prof. Carl A. Kling, Director of State Immunity Institute, Sweden; Dr. Severin, Director of Boys' Camp, Reisingbo, Sweden; and to Dr. Gunnar Svedenius, Medical Director of Girls' Camp, Barnens ర, Sweden, for their interest and cooperation in helping us to get access to their very rich material. Without their assistance, we would not have been able to include the material from Scandinavia and Finland. To Dr. Wertiainen of Loimaa, Finland, we are likewise greatly indebted for putting his cases at our disposal. viously employed, and have subjected the data to statistical analysis. It has been surprising how consistently the figures have supported our earlier contentions that the poliomyelitic susceptible was a specific and recognizable type. But, in addition, the calculations have brought out some new concepts of the possible nature of this poliomyelitic susceptible human host type. One of these involves the problem of growth and development, another has to do with age (time factor) in relation to the distribution and severity of paralysis.

Because the statistical material is so extensive, we have thought it best to present the work in two sections, the first discussing the findings in respect to growth and development, the second those related to age and paralysis. But, it should be understood that because of the complex interrelationships of the two sets of phenomena, a sharp division is impossible.

\section{MEASUREMENTS}

The most notable finding is that paralyzed boys in the age group 5 to 8 and from 13 on possess larger head and face size than do the controls. Between the ages of 9 and 13 the sick and well groups present no differences. But again in the 15 to 20 age group the cripples display significantly greater dimensions in 14 out of 27 measurements. The interpupillary distance and the breadth between the inner canthi is likewise greater among the sick individuals of the earlier and later age groups. Furthermore, their eye slits are longer than those in the well series. ${ }^{8}$

When the entire series is divided into the 2year age groups clear differences in comparative size appear between those which precede and follow puberty. This finding we have considered as a difference in growth rhythm between the two groups (Figure 1). In the later age groups body measurements indicate somewhat greater size among afflicted persons. On the other hand, for a character such as cephalic index we have never found any correlation with types susceptible to infantile paralysis.

3 The detailed data which are available in this laboratory and are not included in this paper because of their magnitude give the differences of the means of all the measurements and indices with the value in terms of the probable error for each age group. 
$M M$

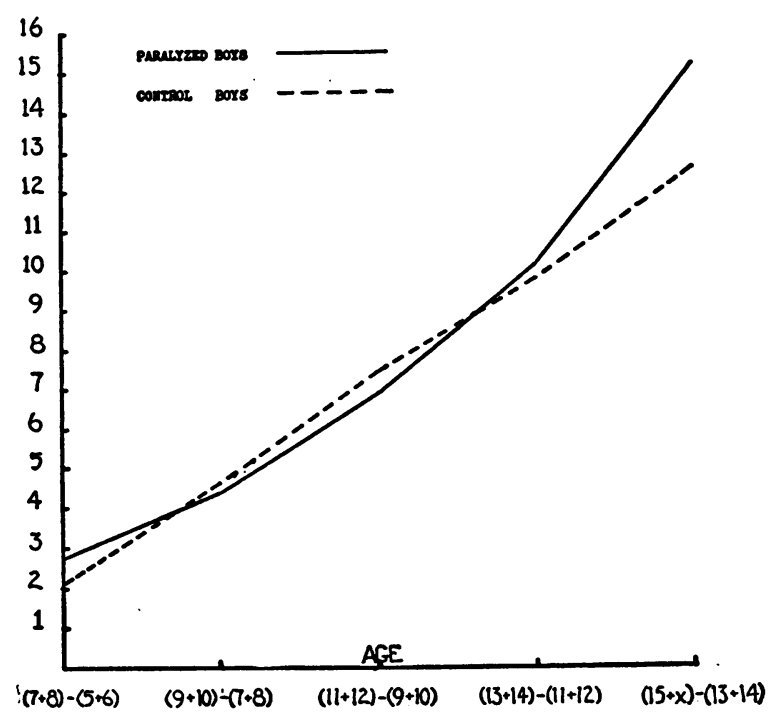

Fig. 1. Curve Showing Accumulated Biennial InCREMENTS OF GROWTH

The increments express the difference, each 2 years, between the means in millimeters of the sum of all linear measurements.

To recapitulate then, it appears that afflicted children tend to be larger in size during the years before and after puberty. But during the time period commonly allocated to the establishment of sexual maturity there is no demonstrable difference in growth achievement between the sick and well groups. Now when we consider the nonmeasureable characters a somewhat different picture confronts us. These phenomena which now present themselves for discussion seem to be related almost exclusively to the function of development. They comprise details of design and tissue quality some of which tend in general to be modified or to disappear with advancing years.

\section{OBSERVATIONS}

We have chosen six characters from among a large number of the observable ones which show significant differences between sick and well groups. These six were chosen because they have been so consistently emphatic. Indeed we have come to rely on them as dependable criteria of the poliomyelitic susceptible constitution. Table I shows the excesses in the frequency (percentage) of these characters in the sick over the well male groups. These differences are also expressed in
TABLE I

Differences of percentages in the six characters between the sick and well groups with values in terms of probable error. Sick boys/Well boys

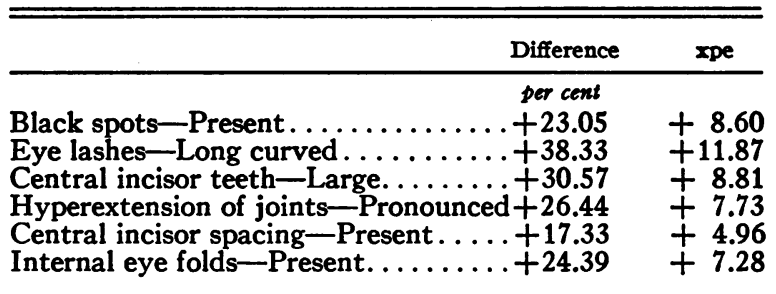

terms of their probable errors. (If the $x p e$ is above 3 the difference is significant.)

Pigment spots. The physiology of pigment in health and disease is not yet fully understood. Consequently it is not possible now to offer a suggestion as to its significance in patients who are susceptible to infantile paralysis. Our findings indicate two things. First, irregularity of pigmentation is definitely more extensive and frequent in our paralyzed series than in the controls. Second, this difference seems to be entirely independent of eye color, hair color, and race.

TABLE II

Black spots-Male series

\begin{tabular}{l|c|c|c|c|c|c}
\hline \hline & \multicolumn{2}{|c|}{ Absent } & \multicolumn{2}{c|}{ Present } & \multicolumn{2}{c}{ Total } \\
\cline { 2 - 7 } & $\begin{array}{c}\text { Num- } \\
\text { ber }\end{array}$ & $\begin{array}{c}\text { Per } \\
\text { cent }\end{array}$ & $\begin{array}{c}\text { Num- } \\
\text { ber }\end{array}$ & $\begin{array}{c}\text { Per } \\
\text { cent }\end{array}$ & $\begin{array}{c}\text { Num- } \\
\text { ber }\end{array}$ & $\begin{array}{c}\text { Per } \\
\text { cent }\end{array}$ \\
\hline Sick total .... & 15 & 10.14 & 133 & 89.86 & 148 & 100.00 \\
Control total . & 76 & 33.19 & 153 & 66.81 & 229 & 100.00 \\
\hline
\end{tabular}

Large central incisors and central incisor spacing. Our figures disclose a greater amount of large and irregular dentition in the sick group. Believing as we do that the manner of dental eruption expresses an important index of the total organism's growth and development, tooth form and placement are for us matters of constitutional significance.

TABLE III

Size of central incisor teeth-Male series (Ages 7 and above only)

\begin{tabular}{|c|c|c|c|c|c|c|}
\hline & \multicolumn{2}{|c|}{$\begin{array}{c}\text { Small and } \\
\text { average }\end{array}$} & \multicolumn{2}{|c|}{ Large } & \multicolumn{2}{|c|}{ Total } \\
\hline & $\underset{\text { ber }}{\text { Num- }}$ & $\begin{array}{l}\text { Per } \\
\text { cent }\end{array}$ & $\underset{\text { ber }}{\text { Num- }}$ & $\begin{array}{c}\text { Per } \\
\text { cent }\end{array}$ & $\underset{\text { ber }}{\text { Num- }}$ & $\begin{array}{l}\text { Per } \\
\text { cent }\end{array}$ \\
\hline $\begin{array}{l}\text { Sick total.... } \\
\text { Control total . }\end{array}$ & $\begin{array}{l}21 \\
99\end{array}$ & $\begin{array}{l}16.80 \\
47.37\end{array}$ & $\begin{array}{l}104 \\
110\end{array}$ & $\begin{array}{l}83.20 \\
52.63\end{array}$ & $\begin{array}{l}125 \\
209\end{array}$ & $\begin{array}{l}100.00 \\
100.00\end{array}$ \\
\hline
\end{tabular}


TABLE IV

Central incisor spacing-Male series

\begin{tabular}{l|r|c|c|c|c|c}
\hline \hline & \multicolumn{2}{|c|}{ Absent } & \multicolumn{2}{c|}{ Present } & \multicolumn{2}{c}{ Total } \\
\cline { 2 - 7 } & $\begin{array}{c}\text { Num- } \\
\text { ber }\end{array}$ & $\begin{array}{c}\text { Per } \\
\text { cent }\end{array}$ & $\begin{array}{c}\text { Num- } \\
\text { ber }\end{array}$ & $\begin{array}{c}\text { Per } \\
\text { cent }\end{array}$ & $\begin{array}{c}\text { Num- } \\
\text { ber }\end{array}$ & $\begin{array}{c}\text { Per } \\
\text { cent }\end{array}$ \\
\hline Sick total .... & 70 & 47.30 & 78 & 52.70 & 148 & 100.00 \\
Control total . & 148 & 64.63 & 81 & 35.37 & 229 & 100.00 \\
\hline
\end{tabular}

Eyelashes. In the control group eyelashes tend to grow shorter with advancing years. In the paralyzed group, on the other hand, there is no shortening as they grow older. We have as yet no explanation for this phenomenon. But it is again one which displays a different conduct in relation to increasing maturity between the sick and well groups.

TABLE $\mathbf{v}$

Eyelashes-Male series

\begin{tabular}{|c|c|c|c|c|c|c|}
\hline & \multicolumn{2}{|c|}{$\begin{array}{l}\text { Short or } \\
\text { medium }\end{array}$} & \multicolumn{2}{|c|}{ Long curved } & \multicolumn{2}{|c|}{ Total } \\
\hline & $\underset{\text { ber }}{\text { Num- }}$ & $\begin{array}{l}\text { Per } \\
\text { cent }\end{array}$ & Num- & $\begin{array}{c}\text { Per } \\
\text { cent }\end{array}$ & $\underset{\text { ber }}{\text { Num- }}$ & $\begin{array}{l}\text { Per } \\
\text { cent }\end{array}$ \\
\hline $\begin{array}{l}\text { Sick total. . . } \\
\text { Control total }\end{array}$ & $\begin{array}{r}26 \\
128\end{array}$ & $\begin{array}{l}17.57 \\
55.90\end{array}$ & $\begin{array}{l}122 \\
101\end{array}$ & $\begin{array}{l}82.43 \\
44.10\end{array}$ & $\begin{array}{l}148 \\
229\end{array}$ & $\begin{array}{l}100.00 \\
100.00\end{array}$ \\
\hline
\end{tabular}

Hyperextensibility of joints. Hyperextensibility of hand and fingers is a universal character of human infants. It disappears at a varying rate with advancing years until a sharp drop occurs at about 13 years of age. Among infantile paralysis patients, however, there is a much higher percentage of hyperextensibility in all age groups. But the curve of descent practically parallels that of the control group.

TABLE VI

Hyperextensibility of joints-Male series

\begin{tabular}{l|c|c|c|c|c|c}
\hline \hline & \multicolumn{2}{|c|}{$\begin{array}{c}\text { Absent to } \\
\text { medium }\end{array}$} & Pronounced & \multicolumn{2}{|c}{ Total } \\
\cline { 2 - 7 } & $\begin{array}{c}\text { Num- } \\
\text { ber }\end{array}$ & $\begin{array}{c}\text { Per } \\
\text { cent }\end{array}$ & $\begin{array}{c}\text { Num- } \\
\text { ber }\end{array}$ & $\begin{array}{c}\text { Per } \\
\text { cent }\end{array}$ & $\begin{array}{c}\text { Num- } \\
\text { ber }\end{array}$ & $\begin{array}{c}\text { Per } \\
\text { cent }\end{array}$ \\
\hline Sick total .... & $\mathbf{5 2}$ & $\mathbf{3 5 . 1 3}$ & $\begin{array}{c}96 \\
\mathbf{6 0}\end{array}$ & $\begin{array}{c}64.87 \\
38.43\end{array}$ & $\begin{array}{c}148 \\
229\end{array}$ & $\begin{array}{c}100.00 \\
100.00\end{array}$ \\
\hline
\end{tabular}

Internal eyefolds (Epicanthic, "Mongoloid"). The three well known characters of the Mongol eye are : 1, Inner canthus lower than outer giving a slant to the palpebral fissure; 2 , a smooth downward and inward curve of the upper lid margin; 3 , the epicanthal fold of skin which sweeps down almost vertically over the inner canthus. Various elements of this trio or all of them are not infrequently seen in members of the white race. This eye construction is usually associated with a flat nose bridge and wide inter-inner canthus space.

TABLE VII

Internal eyefolds-Male series

\begin{tabular}{l|c|c|c|c|c|c}
\hline \hline & \multicolumn{2}{|c|}{ Absent } & \multicolumn{2}{c|}{ Present } & \multicolumn{2}{c}{ Total } \\
\cline { 2 - 7 } & $\begin{array}{c}\text { Num- } \\
\text { ber }\end{array}$ & $\begin{array}{c}\text { Per } \\
\text { cent }\end{array}$ & $\begin{array}{c}\text { Num- } \\
\text { ber }\end{array}$ & $\begin{array}{c}\text { Per } \\
\text { cent }\end{array}$ & $\begin{array}{c}\text { Num- } \\
\text { ber }\end{array}$ & $\begin{array}{c}\text { Per } \\
\text { cent }\end{array}$ \\
\hline Sick total .... & 77 & 52.03 & 71 & 47.97 & 148 & 100.00 \\
Control total & 175 & 76.42 & 54 & 23.58 & 229 & 100.00 \\
\hline
\end{tabular}

Our findings show this character in one or more of its constituent forms to be present far more often among the paralyzed than the well. Furthermore, there were three Mongoloid idiots in Willard Parker Hospital suffering from acute poliomyelitis during the 1931 epidemic. The population incidence of such arrested types is 1 in 1000 of child population. The cause of Mongolism is not known. But this peculiar condition is now thought to be caused by some adverse intrauterine influence which results in a special form of retardation in growth and development. Disturbance of anterior pituitary lobe, adrenal cortex, and gonads have been suggested. It is also worth noting that the epicanthal fold, flat nose bridge, and wide inter-inner canthus space, and wide set eyes is almost typical of the white fetus.

The marked difference of facial design between fetus, infant, and adult is well known and depends largely on elevation of the nose bridge. Our figures show, for example, that the inter-inner canthus breadth is significantly greater for the patients than the controls, for the age groups 5 to 6 and 7 to 8 years. This difference between sick and well group is not so marked at puberty. But it persists as one of the insignia of retardation in many older paralyzed children to later ages than the controls.

While the two methods-mensuration and observation-are obviously only applicable in their appropriate fields the findings of each method are 
naturally intimately interwoven. Table VIII, derived from stricken girls over 7 years of age, is offered as an example of the interrelation. Should we take, for example, the figure which represents the ratio, "interpupillary space over facial diameter," this whole group can be divided into twoone of which displays indices below 47 , the other 48 and above. If now the members of these two groups be classified according to the number of the six characters each possesses, the structure of Table VIII becomes clear. The figures show apparently that when the index is low (i.e., below 47) 80 per cent of such individuals possess only one of the six characters. When the index is high (above 48) on the other hand, the individuals tend to present an increasing number of the six characters. This would again indicate that with increase in size (growth) there is found an increase in criteria of inadequate development.

TABLE VIII

Paralyzed girls, ages 7 and over.

Interpupillary space/Facial diameter

\begin{tabular}{|c|c|c|}
\hline Number of characters & $\begin{array}{l}\text { Low } \\
\text { index, } \\
\text { up to } 47\end{array}$ & $\begin{array}{c}\text { High } \\
\text { index,* }\end{array}$ \\
\hline $\begin{array}{l}\text { I (One character). } \\
\text { II (Two characters) } \\
\text { III (Three characters) } \\
\text { IV (Four characters). } \\
\text { V (Five characters). } \\
\text { VI (Six characters). }\end{array}$ & $\begin{array}{l}\text { per cent } \\
\ldots 80.00 \\
\ldots 57.14 \\
\ldots 77.78 \\
\ldots 55.56 \\
\ldots 48.57 \\
\ldots 36.36\end{array}$ & $\begin{array}{c}\text { per cent } \\
20.00 \\
42.86 \\
22.22 \\
44.44 \\
51.43 \\
63.64\end{array}$ \\
\hline
\end{tabular}

${ }^{*}$ Low index $=$ narrow eye set relative to face breadth. High index $=$ wide eye set relative to face breadth.

In the first two age groups we have seen the analogue of the fetal face, suggesting a retardation in the metamorphosis of this important facial area (Figure 2). The term retardation here does not refer to size, for often these retarded faces are large. It refers to the degree of maturity. The subsequent pushing forward of the nose bridge with advancing months and years rapidly changes the fetal and infant aspects in the direction of adult nasalization. In the age groups 9 to 13 these special eye-nose zone characters show little or no difference between sick and well. But from then on the fetal and infantile resemblances reappear in subtly varying degree among the paralyzed group. It is as if the sick group were capable to some extent of pushing the nose bridge forward from the original fetal eye and nose design. But it only goes so far. On the other

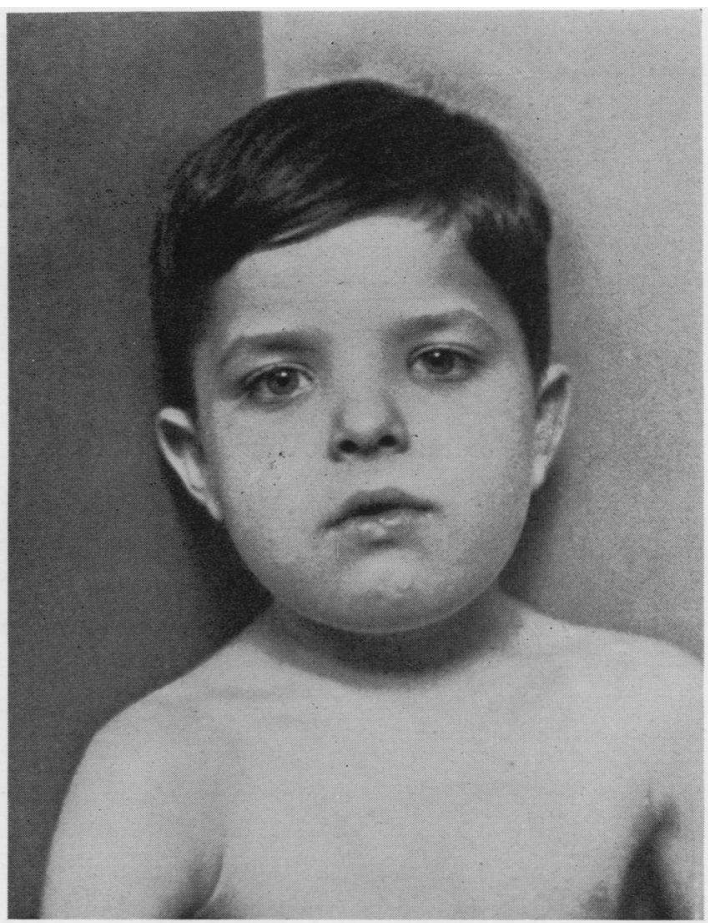

Fig. 2. Boy of 7 Showing Facial Characters of Poliomyelitic Susceptible Type

Note excessive inter-inner canthus space and Mongoloid fold, also black spot on left chest. This boy also has widely separated upper central incisors, flat nose bridge, and wide set eyes.

hand the well group at this point maintain the continuing nasal growth process appropriate to the 9 to 12 age level. Then with the puberty thrust they forge ahead. The sick group are left behind and remain fixed at some point of retardation. So far as eye-nose zone is concerned such retardation is more notable by contrast as the rest of the face grows more mature.

Another phenomenon which presents a somewhat similar picture of discrepancy between advance in general body growth and functional retardation is found in the external genitalia of male paralytics. Not only are small organs almost the rule among the sick group, but partial or complete cryptorchidism is significantly more common in the stricken than in the resistant persons. Coincident with the retardation in gonad development it was observed that the body build in the paralyzed boys tended more towards the curved "feminine" (perhaps better, the " human species type" which underlies that of both sexes) as compared with the more angular "masculine" 
body build of the well boys. The inverse ratio of large body size and small gonads again points to a lack of parallelism between the two important phases of the maturing process.

It should be evident from the foregoing paragraphs that we are confronted with the two complex and intimately associated phenomena of growth and development. They seem to be as definitely related to the unsuccessful maturing of a specifically ill person as they may be to the final completion of a healthy specimen. We have considered that the two words "Growth" and "Development" have different connotations but that the processes they describe are importantly related, indeed perhaps merged. Growth for us means augmentation in size: Development on the other hand connotes the continuous modification of an individual's total life processes which transpire between the egg stage and adult form. It deals not with size but with events of functional rearrangement and especially with the time at which these events occur, and their relation to one another in respect to the time of their occurrence. Furthermore, since both growth and development express energy in motion their relationship with time determines rate. The importance of the rate of growth and development of the parts of an organism is well known to be a matter of profound significance to the successful completion of the adult phenotype. Stockard's (11) experiments on the production of various degrees of twinning in trout by retarding the metabolism rate of germinating eggs is an excellent illustration of the importance of pace for maturing embryos. Newman (12) has published somewhat similar studies.

Our findings would seem to show that the susceptibility to the virus of infantile paralysis is part of' a definite type of faulty constitution. As in all other biological phenomena there is a wide range in the degree, but we believe that there is adequate support for the notion that poliomyelitic susceptibles are different from the resistant persons. These differences are doubtless relative and as subtly relative as are the merging tones of the chromatic scale in music. From this it might be inferred that the number and degree of the characters-the legibility of the stamp as it were -may correlate positively with the severity of the disease-whether abortive or paralyzed, including the latter's distribution and extent.
It is interesting that anthropometry demonstrated less evidence of difference between sick and well than did the observations of non-measurable characters. Possibly, the explanation for this lies in the fact that growth (in the sense of size augmentation) is not perhaps so closely involved with susceptibility. Resistance to infection on the other hand is more intimately related to the changing functions of metamorphosing cells. And so it would seem as though there were a splitting of the two forces which carry the organism to completion. Among poliomyelitic susceptibles there is a tendency to overgrowth and underdevelopment. The latter persists while growth continues and emphasizes the developmental retardation. Among non-susceptibles, growth and development proceed more in step with each other and with age (time appropriateness). These growth irregularities and developmental retardations, as well as the sex difference in the attack rate suggest adverse genetic, or intrauterine forces, and later endocrine unbalance as being responsible for the type susceptible to infantile paralysis.

\section{CONCLUSIONS}

1. A method composed of mensuration, observation, and statistical analysis has been used for studying the external morphology of subjects with infantile paralysis.

2. Persons susceptible to the virus of acute anterior poliomyelitis possess a special constitutional type of morphology which differs significantly from that of non-susceptibles.

3. Variations occur in the degree of the morphological differences extending from nearly imperceptible ones to those of high statistical significance. This scale may parallel the severity of the individual illness, and likewise possess epidemiological significance.

4. Among susceptibles there is a lack of coordination between growth and development. This is expressed in a tendency to overgrowth and retarded development.

5. The peculiar presence of the Mongoloid eye and the fetal and infant-like retardation of the eye-nose zone suggest adverse genetic or intrauterine forces.

6. The person susceptible to infantile paralysis is a different and in some way incomplete phenotype; the incompleteness depending upon certain 
faulty genetic characters, or adverse intrauterine events which alter the time relationships in the processes of growth and development.

\section{ADDENDA}

Following is a list of the anthropological measurements and indices derived from them:

\author{
Cephalic length \\ Cephalic breadth \\ Facial diameter \\ Bigonial diameter \\ Facial height \\ Nasion-prosthion \\ Nasal height \\ Nasal breadth \\ Infradentale-menton \\ Ear length \\ Ear breadth \\ Interpupillary space \\ Palpebral length \\ Palpebral breadth \\ Inter-inner canthus \\ Nail length \\ Nail breadth \\ Finger length \\ Hand length \\ Palm length \\ Palm breadth \\ Gonial angle \\ Biacromial diameter
}

Biiliac diameter Thoracic lateral diameter Thoracic A.P. diameter Webb

Cephalic index

Facial index

Upper face index

Nasal index

Ear index

Palpebral index

Nail index

Hand index

Thoracic index

Biiliac diameter/

Biacromial diameter

Interpupillary space/ Nasion prosthion

Interpupillary space/ Facial diameter

Bigonial diameter/ Facial diameter

Inter-inner canthus/ Facial diameter

\section{BIBLIOGRAPHY}

1. Draper, G., Acute Anterior Poliomyelitis. P. Blakiston's Son and Co., Philadelphia, 1917.

2. Draper, G., The nature of the human factor in infantile paralysis. Am. J. M. Sc., 1932, 184, 111.

3. Levine, M. I., Neal, J. B., and Park, W. H., Relation of physical characteristics to susceptibility to anterior poliomyelitis. J. A. M. A., 1933, 100, 160.

4. Thelander, H. E., and Pryor, H. B., Anthropometric and anthroposcopic studies of poliomyelitis. Arch. Pediat., 1933, 50, 749.

5. Underwood, Michael, Treatise on Diseases of Children. London, 1799.

6. Shaw, J., On the Nature and Treatment of the Distortions to which the Spine and the Bones of the Chest are Subject. Longman Hurst, London, 1823.

7. Aycock, W. L., Nature of autarceologic susceptibility to poliomyelitis. Am. J. Pub. Health, 1937, 27, 575.

8. Webster, L. T., Inherited and acquired factors in resistance to infection. J. Exper. Med., 1933, 57, 793.

9. Webster, L. T., Inheritance of resistance of mice to enteric bacteria and neurotropic virus infections. J. Exper. Med., 1937, 60, 261.

10. Aycock, W. L., Autarceology of poliomyelitis. West Virginia M. J., 1934, 30, 481.

11. Stockard, C. R., Developmental rate and structural expression. Am. J. Anat., 1931, 28, 115.

12. Newman, $H$. H., On the production of monsters by hybridisation. Biol. Bull., 1917, 32, 306. 